\title{
Copper, zinc and iron levels in infants and their mothers during the first year of life: a prospective study
}

Tülin Ayşe Özden ${ }^{*}$, Gülbin Gökçay², M. Serdar Cantez ${ }^{3}$, Özlem Durmaz ${ }^{3}$, Halim İşsever ${ }^{4}$, Beyhan Ömer ${ }^{5}$ and Günay Saner ${ }^{2}$

\begin{abstract}
Background: Essential micronutrients are important for maintenance of life. Deficiency of micronutrients is more likely to be encountered in children, and women studies are required to investigate the status of micronutrients in children and women. This study aimed to longitudinally evaluate changes in zinc, copper, and iron levels in breastfed infants and their mothers during the first year of life.

Methods: Serum and hair samples were obtained from 35 healthy breastfed infants (51\% males, $49 \%$ females) and their mothers 2, 6, and 12 months after delivery. All of the samples were assessed using an atomic absorption spectrophotometer. Serum iron levels were determined by a Roche/Hitachi/Modular analyzer. Statistical analyses were performed using SPSS-PC (Version 21.00) software.

Results: Hair zinc $(p<0.05)$ and serum iron $(p<0.001)$ levels of infants were significantly decreased towards the end of the first year. Infants' serum copper levels were increased towards the end of the first year. Maternal serum and hair copper levels and serum iron levels were significantly decreased towards the end of the first year. There were no significant correlations between dietary zinc, copper, iron intake, and trace element levels of infants and their mothers.

Conclusions: Infants' hair zinc levels, maternal and infants' hair copper levels, and infants' and maternal serum iron levels declined towards the end of the first year. Infants need more zinc after 6 months of age. Infants' and mothers' daily iron intake was less than the recommended intake.
\end{abstract}

Keywords: Infant, Mother, Serum trace elements, Hair trace elements, Breastfeeding, Diet

\section{Background}

Copper $(\mathrm{Cu})$, zinc $(\mathrm{Zn})$, and iron $(\mathrm{Fe})$ are essential micronutrients for maintenance of life. These micronutrients are involved in many complex enzyme systems functioning in various biological processes [1-6]. Deficiency of trace element nutrients is more likely to be encountered in children, and pregnant and lactating women $[7,8]$. There are interactions between some trace elements. Deficiency in one trace element may impair absorption of another (e.g., $\mathrm{Cu}$ deficiency impairs Fe absorption). Fe and $\mathrm{Zn}$ interact at the level of the intestinal mucosa and $\mathrm{Zn}$

\footnotetext{
* Correspondence: tulozden@istanbul.edu.tr

'Department of Pediatrics, Istanbul Faculty of Medicine, Istanbul University, Trace Element Unit, 34093 Istanbul, Turkey

Full list of author information is available at the end of the article
}

absorption is impaired by Fe $[9,10]$. There is also a strong interaction between $\mathrm{Zn}$ and $\mathrm{Cu}$, and they compete at the level of intestinal absorption [11]. High $\mathrm{Zn}$ levels in the diet can reduce the absorption of $\mathrm{Cu}$, but high dietary $\mathrm{Cu}$ does not decrease absorption of $\mathrm{Zn}$ [12].

Inadequate intake of $\mathrm{Zn}$ is considered to be responsible for $20 \%$ of global child mortality [13]. Children with iron deficiency anemia have high serum $\mathrm{Cu}$ levels and low serum $\mathrm{Zn}$ levels [14]. Trace element deficiencies arise from low dietary intake and develop especially when requirements are increased or body stores are depleted. Absorption of trace elements may be impaired by increased intake of dietary components, such as phytate or excessive intake of mineral supplements $[11,15]$. Another possible mechanism for trace element deficiency is 
excessive excretion or use. Zinc and copper deficiency is also found in malabsorption syndromes, such as chronic diarrhea, coeliac disease, inflammatory bowel disease, ileostomy, alcoholic cirrhosis, and hemolytic anemia [16].

Zinc as a trace element has three important functional roles: catalytic, structural, and regulatory $[3,5]$. Copper has an antioxidant role that protects cells from freeradical injury $[3,17]$. Copper also contributes to the formation of ceruloplasmin, which has a role in iron metabolism. Copper is required to absorb and use Fe [1, 14, $17,18]$. Infants and young children in developing countries are particularly vulnerable to Fe and Zn deficiency because of increased requirements, low bioavailability, and recurrent infections $[7,18]$.

Copper deficiency is rare, but it has been reported in preterm infants, in infants fed with cow's milk, and in infants recovering from malnutrition accompanied by diarrhea [6,19-21]. Deficiency of $\mathrm{Cu}$ leads to anemia, neutropenia, impairment of growth, abnormalities in glucose and cholesterol metabolism, and increased rates of infection [22].

Iron is another essential trace element that functions in the synthesis of hemoglobin and myoglobin [23]. A total of $25 \%$ of the world's population is thought to be affected by Fe deficiency. Infants aged between 4 and 24 months, school-age children, females, adolescents, and pregnant and lactating mothers are most affected by this deficiency [24].

Serum concentrations are useful parameters to assess trace elements, but they are not sufficiently specific and sensitive to detect mild deficiency $[25,26]$. Hair shaft $\mathrm{Zn}$ and $\mathrm{Cu}$ levels are useful parameters to determine the quantity of trace elements that is available to the hair follicles at the time of growth, rather than the actual time that children are sampled. Hair trace element levels have been proposed as a useful index of the long-term status of trace elements [27]. Therefore, studies are required to investigate the status of trace elements and their interactions among each other in infants. To the best of our knowledge, there are no longitudinal cohort studies that have investigated the $\mathrm{Cu}, \mathrm{Zn}$, and $\mathrm{Fe}$ status of breastfed infants and their mothers. There is one relevant study, but it is not a cohort study [28].

Therefore, the present study aimed to longitudinally evaluate the changes in $\mathrm{Zn}, \mathrm{Cu}$, and Fe levels of breastfed infants and their mothers after delivery during the first year of life.

\section{Methods}

This longitudinal study was conducted between December 2007 and January 2010 in two month-old infants who were attending the Well Child Unit of Istanbul Medical School, Istanbul University. Blood and hair samples were obtained from 111 infants and their mothers 2 months after delivery. Although there were 111 infants and mothers at the beginning of the study, we lost 76 participants (loss to follow-up group) because of infection, medicine use, and vitamin use, and some did not continue to visit the clinic. Blood and hair samples were collected longitudinally from 35 infants (18 males, 17 females) and their mothers 2,6 , and 12 months after delivery.

Inclusion criteria for the study were as follows: uneventful pregnancy, term delivery, and birth weight $\geq 2500 \mathrm{~g}$ with no apparent congenital defects. Children born at the Maternity Clinic of the University Hospital constituted the majority of the infants and the children who were followed up at the clinic. Specimens were collected by convenience sampling. Children with any proven or suspected infection at the time of collection of samples were excluded from the study. All of the samples were assessed using an atomic absorption spectrophotometer (Varian Spectra AA 200, GTA-100, Australia). Serum Fe levels were determined by a Roche/Hitachi/ Modular analyzer, japan.

A complete physical examination, including anthropometric measurements, was performed for each infant. Weight, length, and head circumference measurements were performed by two trained nurses. $\mathrm{Z}$ scores for length, weight, and head circumference measurements of infants were calculated with a computerized program that was developed for Turkish children [29, 30]. This study was supported by the Istanbul University Research Fund. Written consent was obtained from the parents. Approval of the Medical School Ethical Committee was obtained at the beginning of the study.

\section{Collection of data and specimens, and laboratory procedures}

A validated questionnaire that was specific for this project was developed in a pilot study to collect data on the feeding habits of infants and their mothers. All of the mothers were on Fe and folic acid supplementation during pregnancy. Daily and weekly consumption of meat, milk, eggs, and vegetables was recorded. Infants were classified as either exclusively breastfed (infants receiving only breast milk, not even water), partially breastfed, or non-breastfed. Data on daily intake of $\mathrm{Zn}, \mathrm{Cu}, \mathrm{Fe}$, and meat in infants and their mothers were calculated using a computerized nutrient analysis program (BEBiS), which has been adapted for Turkish infants and their families. Infants' dietary habits were evaluated only once at 12 months and mothers' dietary habits were evaluated 2, 6, and 12 months after delivery. For evaluation of breast milk intake, the duration of each feed was used to estimate the likely volume of milk. A feed lasting $10 \mathrm{~min}$ or longer was assumed to be $100 \mathrm{ml}$ in volume (i.e., $10 \mathrm{ml}$ per min) and a proportion of this if the feed was 
of shorter duration [31]. For example for a feeding lasting $5 \mathrm{~min}$, the milk intake was assumed to be $50 \mathrm{ml}$.

Blood specimens were collected after a fasting period of 8 or $10 \mathrm{~h}$ for mothers and $4 \mathrm{~h}$ for infants. Trace element-free syringes, stainless steel needles, and special trace element tubes (Becton-Dickinson) were used.

The serum samples were separated after $10 \mathrm{~min}$ of centrifugation. Serum samples were diluted at a 1:6 ratio with bi-distilled water. Serum $\mathrm{Zn}$ and $\mathrm{Cu}$ concentrations were measured using an atomic absorption flame emission spectrophotometer (Varian AA 100, Australia) (213.9 $\mathrm{nm}$ and 324.8, respectively) [32, 33]. A standard curve was established using a commercial $\mathrm{Zn}$ and $\mathrm{Cu}$ reference (Merck KGaA Darmstadt, Germany). The coefficient of variation of the measurements was always below $5 \%$.

Hair samples of infants and their mothers were collected from the suboccipital area of the head. Divided hair samples were sequentially washed three times in hexane, analytical grade ethanol, and fresh bi-distilled water. They were dried at $75{ }^{\circ} \mathrm{C}$ in a vacuum oven overnight in polyethylene vial and weighed $20-100 \mathrm{mg}$. The hair was digested using perchloric acid and nitric acid. Digestion was performed between 65 and $75{ }^{\circ} \mathrm{C}$ [33, 34]. The ashed samples were dissolved in $1 \mathrm{~mL}$ of bi-distilled water and $10-\mu \mathrm{L}$ aliquots were injected into a graphite furnace with an auto sampler. Bovine liver certified standard (SRM no. 1577c certified; National Institute of Standard and Technology) and a pooled hair sample were similarly digested in perchloric acid and nitric acid, and were used as internal standards. A standard curve was established using a commercial $\mathrm{Zn}$ and $\mathrm{Cu}$ reference (Merck $\mathrm{KGaA}$ ). Hair $\mathrm{Zn}$ and $\mathrm{Cu}$ concentrations were determined using a Varian Spectra AA 200 atomic absorption spectrophotometer equipped with a GTA-100 [32-34]. Hair $\mathrm{Zn}$ and $\mathrm{Cu}$ levels are expressed in $\mu \mathrm{mol} / \mathrm{g}$, and serum levels of $\mathrm{Zn}$ and $\mathrm{Cu}$ are expressed in $\mu \mathrm{mol} / \mathrm{g}$. Serum and hair $\mathrm{Zn}$ levels lower than $10.70 \mu \mathrm{mol} / \mathrm{L}$ and $1.07 \mu \mathrm{mol} / \mathrm{g}$, respectively, were accepted as low levels [27, 35]. Normal serum $\mathrm{Cu}$ levels have been reported as between 3.15 and $11 \mu \mathrm{mol} / \mathrm{L}$ in infants aged up to 6 months of age, (mean \pm SD) $17.50 \pm 4.10 \mu \mathrm{mol} / \mathrm{L}$ for infants aged from 6 months to 2 years, and 12.60$24.40 \mu \mathrm{mol} / \mathrm{L}$ for females [36-38]. There is no exact cut off level for hair $\mathrm{Cu}$ levels for infants in the literature. Serum iron levels less than $8.95 \mu \mathrm{mol} / \mathrm{L}$ were accepted as low [39].

\section{Statistical analysis}

Statistical analyses were performed using SPSS-PC (IBM Corp; Version 21.00) software. Pearson $\chi^{2}$ analysis for non-continuous, the Student's $t$-test for continuous, and the Mann-Whitney $U$ test for non-normal distribution variables were performed between the groups of "loss to follow-up" and "completed the study".
Final analysis of the study was based on the ones completed the study. Data of hair samples did not have a normal distribution. Therefore, $\chi^{2}$ Friedman and Wilcoxon ranks tests were used for analyses. Data of serum $\mathrm{Zn}, \mathrm{Cu}$, and Fe levels had a normal distribution. Therefore, repeated ANOVA and Paired sample t-tests were used for these cohort specimens. One Way ANOVA test was used to compare daily $\mathrm{Zn}, \mathrm{Cu}$, and Fe intake according to months. Spearman's and Pearson's correlation tests were used to determine relationships. Values of $p<0.05$ were accepted as statistically significant.

\section{Results}

This study was limited to neonates who were born at the Maternity Clinic of Istanbul Medical School. At discharge from the Maternity Clinic, each mother received a pamphlet with information on the Well Child Clinic. Families had relative socio-economic and cultural homogeneity in this study. All of the families were well above the poverty line, as assessed by their ability to bring their neonate to our center. All of the parents were literate. The majority of the mothers were high school graduates. Preterm infants born before 37 gestational weeks were not followed up at the Well Child Clinic.

The majority of the parents in the study had at least 5 years of schooling. Sociodemographic characteristics of infants and their mothers are shown in Table 1. Weight, length, and head circumference $\mathrm{Z}$ scores of all of the infants were within normal limits (Table 2). All 35 infants (18 males, 17 females) and their mothers were followed up until the children were aged 1 year. The breastfeeding status of all infants, parity, and maternal age are shown in Table 1. Hair trace element levels were not normally distributed. Therefore, $95 \%$ confidence intervals and median levels are shown in Table 3.

With regard to sociodemographic characteristics, there were no significant differences between the groups "loss to follow-up" and "completed the study" (Table 1). There were no differences in trace elements between these groups.

Infants' and mothers' serum zinc levels were not significantly different during the follow-up period (Table 3). As shown in Table 3 hair $\mathrm{Zn}$ levels of infants were significantly lower at the ages of 6,12 months than those at 2 months $(p<0.05 ; p<0.001$, respectively). Mothers' hair zinc levels were significantly higher at 6 months after delivery compared with those at 2 and 12 months (Table 3). Three $(8.50 \%)$ infants in the 2 nd month, five $(14.30 \%)$ in the 6th month, and $6(17 \%)$ at 1 year had serum $\mathrm{Zn}$ levels below $10.70 \mu \mathrm{mol} / \mathrm{L}$. Among these infants, 48.60, 66 and $77.10 \%$ had hair Zn levels below $1.07 \mu \mathrm{mol} / \mathrm{g}$ at 2,6 , and 12 months, respectively. Among the mothers, 14.30, 2.90, and $2.90 \%$ had serum $\mathrm{Zn}$ levels below $10.70 \mu \mathrm{mol} / \mathrm{L}$, and $20,11.40$, and $11.40 \%$ had hair 
Table 1 Comparison of sociodemographic characteristics of infants and their families

\begin{tabular}{|c|c|c|c|c|c|}
\hline \multirow[t]{2}{*}{ Variables } & \multicolumn{2}{|c|}{ Loss to follow-up } & \multicolumn{2}{|c|}{ Completed the study } & \multirow[b]{2}{*}{ Two-tailed significance } \\
\hline & $n=76$ & $\%$ & $n=35$ & $\%$ & \\
\hline \multicolumn{6}{|l|}{ Sex } \\
\hline Male & 42 & 55.30 & 18 & 51.50 & \multirow[t]{2}{*}{${ }^{\mathrm{a}} 0.14 ; p>0.05$} \\
\hline Female & 34 & 44.70 & 17 & 48.50 & \\
\hline \multicolumn{6}{|l|}{ Maternal education } \\
\hline Primary school & 30 & 39.40 & 8 & 23 & \multirow[t]{3}{*}{${ }^{\mathrm{a}} 2.95 ; p>0.05$} \\
\hline Completed high school & 25 & 33.00 & 15 & 43 & \\
\hline University graduate & 21 & 27.60 & 12 & 34 & \\
\hline \multicolumn{6}{|l|}{ Paternal education } \\
\hline Primary school & 20 & 26.30 & 5 & 14.40 & \multirow[t]{3}{*}{${ }^{a} 3.31 ; p>0.05$} \\
\hline Completed high school & 28 & 36.80 & 12 & 34.30 & \\
\hline University graduate & 28 & 36.80 & 18 & 51.30 & \\
\hline \multicolumn{6}{|l|}{ Maternal occupation } \\
\hline Employee & 11 & 14.47 & 3 & 8.60 & \multirow[t]{5}{*}{${ }^{\mathrm{a}} 0.63 ; p>0.05$} \\
\hline Clerk & 27 & 35.53 & 13 & 37.20 & \\
\hline 'Physician & 1 & 1.32 & 2 & 5.60 & \\
\hline Housewife & 35 & 46.05 & 16 & 45.70 & \\
\hline${ }^{\mathrm{c} O \text { Others }}$ & 2 & 2.63 & 1 & 2.90 & \\
\hline \multicolumn{6}{|c|}{ Feeding status of infants at 2 months } \\
\hline Exclusively breastfed & 63 & 83.00 & 31 & 88.60 & \multirow[t]{2}{*}{${ }^{\mathrm{a}} 0.59 ; p>0.05$} \\
\hline Breast milk + other food & 13 & 17.00 & 4 & 11.40 & \\
\hline \multicolumn{6}{|c|}{ Feeding status of infants at 6 months } \\
\hline Exclusively breastfed & & & 13 & 37.10 & \\
\hline Breast milk + other food & & & 22 & 62.90 & \\
\hline \multicolumn{6}{|c|}{ Feeding status of infants at 12 months } \\
\hline \multirow[t]{2}{*}{ Breast milk + other food } & & & 35 & 100 & \\
\hline & & & & Mean \pm SD & \\
\hline Maternal age (years) & 76 & $30.12 \pm 4.95$ & 35 & $31.30 \pm 4.50$ & $\mathrm{~b}_{\mathrm{t}}=1.20 ; p>0.05$ \\
\hline Parity & 76 & $1.70 \pm 0.66$ & 35 & $1.80 \pm 0.90$ & $\mathrm{~b}_{\mathrm{t}}=0.5 ; p>0.05$ \\
\hline
\end{tabular}

${ }^{\mathrm{a}}$ Pearson $\mathrm{x}^{2}$ analysis and ${ }^{\mathrm{b}}$ Student's t-tests were performed

cPhysicians and others were excluded from the statistical analysis because of their small numbers

Table 2 Z scores of the infants' length, weight, and head circumference

\begin{tabular}{|c|c|c|c|}
\hline Months & 2 & 6 & 12 \\
\hline \multicolumn{4}{|l|}{ Length } \\
\hline Mean \pm SD; median $95 \% \mathrm{Cl}$ & $0.18 \pm 0.91 ; 0.04(-0.13)-(0.48)$ & $0.36 \pm 0.93 ; 0.14(0.052)-(0.67)$ & $0.56 \pm 0.92 ; 0.34(0.26)-(0.86)$ \\
\hline \multicolumn{4}{|l|}{ Weight } \\
\hline Mean \pm SD; median $95 \% \mathrm{Cl}$ & $0.22 \pm 1.07 ; 0.15(-0.13)-(0.57)$ & $0.22 \pm 0.96 ; 0.46(-0.1)-(0.54)$ & $0.10 \pm 0.94 ; 0.12(-0.21)-(0.41)$ \\
\hline \multicolumn{4}{|l|}{ Head circumference } \\
\hline Mean \pm SD; median $95 \% \mathrm{Cl}$ & $-0.33 \pm 1.08 ;-0.50(-0.68)-(0.03)$ & $-0.35 \pm 0.88 ;-0.68(-0.64)-(-0.06)$ & $-0.36 \pm 0.89 ;-0.62(-0.65)-(-0.07)$ \\
\hline
\end{tabular}

Values are mean \pm SD, median levels, and $95 \% \mathrm{Cls}$. Cl confidence interval 
Table 3 Infants' and mothers' serum Zn, Cu, and Fe, and hair Zn and Cu levels

\begin{tabular}{|c|c|c|c|c|c|c|c|c|}
\hline \multirow[b]{2}{*}{$\begin{array}{l}\text { Months after } \\
\text { delivery }\end{array}$} & \multicolumn{3}{|l|}{ Maternal $(n=35)$} & \multirow[t]{2}{*}{ Total $(n=105)$} & \multicolumn{3}{|l|}{ Infants $(n=35)$} & \multirow[t]{2}{*}{ Total $(n=105)$} \\
\hline & 2 & 6 & 12 & & 2 & 6 & 12 & \\
\hline Serum Zn ( $\mu \mathrm{mol} / \mathrm{L})^{\mathrm{a}}$ & $15.00 \pm 3.10^{c}$ & $14.80 \pm 1.50^{c}$ & $14.10 \pm 3.10^{c}$ & $14.7 \pm 2.75^{c}$ & $13.30 \pm 1.50^{d}$ & $13.60 \pm 3.10^{d}$ & $13.50 \pm 3.10^{d}$ & $13.30 \pm 2.70^{d}$ \\
\hline Serum Cu $(\mu \mathrm{mol} / \mathrm{L})^{a}$ & $19.70 \pm 4.70^{\mathrm{e}}$ & $18.70 \pm 3.10^{\mathrm{e}}$ & $18,3 \pm 3.30^{e}$ & $19 \pm 3.3^{e}$ & $14.6 \pm 3.10^{f}$ & $17.20 \pm 3.30^{f}$ & $18.00 \pm 3.10^{f}$ & $16.50 \pm 3.10^{f}$ \\
\hline Serum Fe $(\mu \mathrm{mol} / \mathrm{L})^{\mathrm{a}}$ & $13.10 \pm 5.6^{9}$ & $13.71 \pm 5.40^{9}$ & $12.10 \pm 5.60^{9}$ & $13 \pm 3.8^{9}$ & $12.4 \pm 3.80^{h}$ & $8.70 \pm 3.20^{h}$ & $8.5 . \pm 3.70^{h}$ & $9.85 \pm 4.10^{h}$ \\
\hline $\begin{array}{l}\text { Hair Zn }(\mu \mathrm{mol} / \mathrm{g})^{b} \\
\text { (median; } 95 \% \mathrm{Cl} \\
\text { lower-upper level) }\end{array}$ & $\begin{array}{l}1.48 \pm 0.67^{i} \\
(1.50 ; 1.28-1.72)\end{array}$ & $\begin{array}{l}1.84 \pm 0.75^{i} \\
(1.65 ; 1.60-2.10)\end{array}$ & $\begin{array}{l}1.76 \pm 0.80^{\mathrm{i}} \\
(1.54 ; 1.50-20)\end{array}$ & $\begin{array}{l}1.70 \pm 0.74 \\
(1.50 ; 1.56-1.84)\end{array}$ & $\begin{array}{l}1.30 \pm 0.73^{j} \\
(1.27 ; 1.06-1.55)\end{array}$ & $\begin{array}{l}1.02 \pm 0.50^{j} \\
(0.86 ; 0.87-1.18)\end{array}$ & $\begin{array}{l}0.77 \pm 0.30^{j} \\
(0.79 ; 0.67-0.86)\end{array}$ & $\begin{array}{l}1.03 \pm 0.60^{j} \\
(0.88 ; 0.92-1.14)\end{array}$ \\
\hline $\begin{array}{l}\text { Hair Cu }(\mu \mathrm{mol} / \mathrm{g})^{b} \\
\text { (median; } 95 \% \mathrm{Cl} \\
\text { lower-upper level) }\end{array}$ & $\begin{array}{l}0.20 \pm 0.11^{k} \\
(0.17 ; 0.16-0.24)\end{array}$ & $\begin{array}{l}0.22 \pm 0.11^{\mathrm{k}} \\
(0.19 ; 0.18-0.26)\end{array}$ & $\begin{array}{l}0.17 \pm 0.19^{k} \\
(0.15 ; 0.11-0.19)\end{array}$ & $\begin{array}{l}0.20 \pm 0.11^{k} \\
(0.17 ; 0.18-0.22)\end{array}$ & $\begin{array}{l}0.32 \pm 0.14 \\
(0.32 ; 0.24-0.34)\end{array}$ & $\begin{array}{l}0.34 \pm 0.16 \\
(0.32 ; 0.28-0.39)\end{array}$ & $\begin{array}{l}0.25 \pm 0.13^{\prime} \\
(0.25 ; 0.22-0.32)\end{array}$ & $\begin{array}{l}0.30 \pm 0.16 \\
(0.25 ; 0.27-0.33)\end{array}$ \\
\hline
\end{tabular}

Values are mean \pm SD unless stated otherwise

${ }^{\mathrm{a}}$ Repeated ANOVA and the paired sample $t$-test were used to compare serum $\mathrm{Zn}, \mathrm{Cu}$, and Fe levels

${ }^{\mathrm{b}} \mathrm{X}^{2}$ Friedmanand Wilcoxon rank tests were used for hair analysis

${ }^{C} F_{2,6}=0.66, p>0.05 ; F_{2,12}=2.42, p>0.05, t_{6,12}: 1,24, p>0.05$

${ }^{d} \mathrm{~F}_{2,6}=0.70, p>0.05 ; \mathrm{F}_{2,12}=0.61, p>0.05, \mathrm{t}_{6,12}: 0.09, p>0.05$

${ }^{e} F_{2,6}=2.07, p>0.05 ; F_{2,12}=3.65, p>0.05 ; \mathrm{t}_{6,12}: 0.99, p>0.05$

${ }^{\mathrm{f}_{2}} \mathrm{~F}_{2,6}=8.65, p<0.01 ; \mathrm{F}_{2,12=} 28.03, p>0.001 ; \mathrm{t}_{6,12}: 1,29, p>0.05$

${ }^{9} \mathrm{~F}_{2,6}=0.47, p>0.05 ; \mathrm{F}_{2,12=0.64, p>0.05 ; \mathrm{t}_{6,12}: 1,28, p>0.05}$

$\mathrm{h}_{\mathrm{F}_{2,6}}=21.9, p<0.001 ; \mathrm{F}_{2,12=17.35, p<0.001 ; \mathrm{t}_{6,12}: 0.36, p>0.05}$

' $X$ Friedman $=9.77, p<0.05 ; Z_{2.6}=2.57, p<0.05, Z_{212}=2.58, p<0.05$

${ }^{j}{ }_{\text {Eriedman }}^{2}=19.94, p<0.001 ; Z_{2,6}=2.06, p<0.05, Z_{6,12}=2.53, p<0.01, Z_{2,12}=4.09, p<0.001$

$\mathrm{K}_{\mathrm{X}} \mathrm{K}_{\text {Friedman }}=10.7, p<0.005 ; \mathrm{Z}_{2,6}=2.12, p<0.05, \mathrm{Z}_{2.12}=2.24, p<0.05, \mathrm{Z}_{6.12}=3.00, p<0.005$

$\mathrm{X}$
$\mathrm{X}$
$\mathrm{I}$ 
Zn levels below $1.07 \mu \mathrm{mol} / \mathrm{g}$ at 2, 6, and 12 months after delivery, respectively (Table 4).

Infants' serum $\mathrm{Cu}$ levels at 12 months of age were significantly higher those at 2 and 6 months (Table 3). Infants' serum $\mathrm{Cu}$ levels in the total group $(n=105)$ ranged between 8.70 and $26.80 \mu \mathrm{mol} / \mathrm{L}$. Hair $\mathrm{Cu}$ levels were a minimum of $0.21 \mu \mathrm{mol} / \mathrm{g}$ and a maximum of $0.35 \mu \mathrm{mol} / \mathrm{g}$ in infants and a minimum of $0.14 \mu \mathrm{mol} / \mathrm{g}$ and a maximum of $0.26 \mu \mathrm{mol} / \mathrm{g}$ in mothers. Hair $\mathrm{Cu}$ levels were not normally distributed. Therefore, $95 \%$ confidence intervals and median levels are shown in Table 3. Infants' and mothers' hair $\mathrm{Cu}$ levels were significantly higher at 6 months compared with 2 and 12 months after delivery (Table 3). Maternal serum and hair $\mathrm{Cu}$ levels at 12 months were significantly lower than those at 2 and 12 months. Serum $\mathrm{Cu}$ levels of mothers in the total group $(n=105)$ varied between 13.4 and $24.20 \mu \mathrm{mol} / \mathrm{L}$.

Serum Fe levels of the infants were significantly lower at 12 months than those at 2 and 6 months (Table 3). Maternal serum Fe levels reached a maximum level at 6 months, and then were significantly decreased at 12 months (Table 3). Among the infants, 31.40, 51.40, and $63 \%$ had serum Fe levels less than $8.95 \mu \mathrm{mol} / \mathrm{L}$ at 2, 6, and 12 months, respectively. Among the mothers, $23,11.40$, and $28.60 \%$ had serum Fe levels less than $8.95 \mu \mathrm{mol} / \mathrm{L}$ at 2.6 and 12 months, respectively (Table 4).

The mean daily $\mathrm{Zn}, \mathrm{Cu}$, and $\mathrm{Fe}$ intakes of infants aged 12 months were $3.2 \pm 1.2 \mathrm{mg}, 0.79 \pm 0.32 \mathrm{mg}$, and $3.71 \pm 1.43 \mathrm{mg}$, respectively (Table 5 ). The mean daily $\mathrm{Zn}, \mathrm{Cu}$, and $\mathrm{Fe}$ intakes for mothers were $8.20 \pm$ $2.80 \mathrm{mg}, 1.38 \pm 0.62 \mathrm{mg}$, and $9.15 \pm 2.90 \mathrm{mg}$, respectively. In the second month, the mothers' daily $\mathrm{Zn}, \mathrm{Cu}$, and $\mathrm{Fe}$ intakes were higher than those at 6 and 12 months $(p<0.005)$ (Table 5). Among the mothers, $7.40,59.20$, and $8.50 \%$ consumed red meat, vegetables, and fruit, respectively, every day, but $70.60 \%$ consumed meat less than 2 days a week. There were no significant relationships between dietary $\mathrm{Zn}, \mathrm{Cu}$, and Fe intake and the status of trace elements of infants and their mothers.
Significant positive and negative correlations between trace elements in mothers and infants are shown in Table 6.

\section{Discussion}

This study is one of the few longitudinal studies regarding the status of trace elements in predominantly breastfed healthy infants and their mothers. We found that hair zinc and serum iron levels of infants were significantly lower, while serum copper levels were higher at 12 months than those at 2 and 6 months. Maternal serum and hair copper levels and serum iron levels were significantly decreased in the same period. Zinc, copper, and iron are the predominant nutritional trace elements $[7,8,40]$. The regulatory mechanisms of $\mathrm{Zn}, \mathrm{Cu}$, and $\mathrm{Fe}$ homeostasis are different during pregnancy, lactation, and infancy $[8,18,41,42]$. Further studies are needed to investigate this issue.

\section{Zinc}

During infancy and early childhood, hair zinc concentrations decline from high neonatal values to minimum values at approximately $2-3$ years [27]. This trend in hair $\mathrm{Zn}$ concentrations may arise from gradual depletion of tissue $\mathrm{Zn}$ pools induced by rapid growth. The International Zinc Nutrition Consultative Group concluded that breast milk is a sufficient source of zinc for normal birth weight term infants until approximately 6 months of age [27, 43-45]. Changes in hair $\mathrm{Zn}$ concentrations of breastfed and bottle-fed infants during the first 6 months of life were measured by MacDonald et al. [46], and only the bottle-fed males had a significant decline in hair $\mathrm{Zn}$ concentrations. There was no decline in hair $\mathrm{Zn}$ concentrations in any breastfed infants [46]. In our study, infants' hair $\mathrm{Zn}$ levels significantly declined from high levels at 2 months to low levels at 6 and 12 months (Table 3). Children start to lose endogenous zinc from non-intestinal sites, such as the urinary tract and skin, after 6 months of age, because infants need more $\mathrm{Zn}$ after 6 months of age $[6,27]$. All of the infants' eating habits were included in this evaluation. The infants' dietary habits for $\mathrm{Zn}, \mathrm{Cu}$, and $\mathrm{Fe}$ were evaluated only at

Table 4 Zinc and iron status of mothers and infants after delivery




Table 5 Daily trace element intake of mothers and infants after delivery

\begin{tabular}{|c|c|c|c|c|c|c|}
\hline \multirow[t]{2}{*}{ Months } & \multicolumn{6}{|l|}{ Mothers } \\
\hline & $\mathrm{Zn}$ & & $\mathrm{Cu}$ & & $\mathrm{Fe}$ & \\
\hline 2 & $9.7 \pm 3.80$ & $F=6,63 ; p<0.005$ & $1.69 \pm 0.56$ & $F=6,58 ; p<0.005$ & $10.80 \pm 3.25$ & $\mathrm{~F}=8.26 ; p<0.005$ \\
\hline 6 & $7.4 \pm 2.50$ & & $1.24 \pm 0.59$ & & $8.30 \pm 3.10$ & \\
\hline 12 & $7.6 \pm 2.20$ & & $1.20 \pm 0.72$ & & $8.40 \pm 2.30$ & \\
\hline Total & $8.2 \pm 2.80$ & & $1.38 \pm 0.62$ & & $9.15 \pm 2.90$ & \\
\hline \multicolumn{7}{|l|}{ Infants } \\
\hline 12 & $3.20 \pm 1.20$ & & $0.79 \pm 0.32$ & & $3.71 \pm 1.43$ & \\
\hline
\end{tabular}

Values are mean \pm SD

One Way ANOVA test was used to compare daily $\mathrm{Zn}, \mathrm{Cu}$, and Fe intake according to months

12 months using a computerized nutrient analysis program (BEBiS), which has been adapted for Turkish infants and their families.

A meta-analysis in Turkey that included 17 studies showed that the mean serum $\mathrm{Zn}$ level of 336 children aged between 1 and 3 months was $14.10 \pm 3.70 \mu \mathrm{mol} / \mathrm{L}$ [47]. Another meta-analysis of 28 studies in Turkish adults $(n=4298)$ showed that the mean serum $\mathrm{Zn}$ level was $14.50 \pm 2.91 \mu \mathrm{mol} / \mathrm{L}$ [47]. In our study, the mean serum $\mathrm{Zn}$ level of infants at all ages was slightly lower than that in previous results mentioned above [47]. However, the mothers' serum Zn levels were similar to those of Turkish adult levels.

Some authors have reported that dietary maternal zinc intake during lactation is approximately $13-15 \mathrm{mg} /$ day $[44,48]$. The recommended intake of $\mathrm{Zn}$ for lactating mothers is $12-13 \mathrm{mg} /$ day [49]. The mean daily dietary zinc intake of lactating mothers in our study was lower than these estimated requirements. Similar low findings have also been previously reported for lactating mothers $[50,51]$. In our study, the mean daily $\mathrm{Zn}$ intake of all infants at 12 months was close to the recommended intake (3 mg/day) for infants aged 7-12 months [6]. Nevertheless, we did not gather information on phytatecontaining food intake in our study.

\section{Copper}

There are few studies on children's hair $\mathrm{Cu}$ levels [52, 53]. Park et al. [52] reported that the mean hair copper level in 655 preschool children was $0.24 \pm 0.16 \mu \mathrm{mol} / \mathrm{g}$. Throughout the whole study period hair $\mathrm{Cu}$ levels changed between 0.27 and $0.33 \mu \mathrm{mol} / \mathrm{g}$ in infants and between 0.18 and $0.22 \mu \mathrm{mol} / \mathrm{g}$ in mothers. These results are similar to those in the [52-55]. Eatough et al. [54] reported that hair $\mathrm{Cu}$ levels slightly decreased with age. Maternal and infants' hair $\mathrm{Cu}$ levels reached their maximum level at 6 months and then decreased at 1 year in our study. Salmenpera et al. [55] reported that infants' serum $\mathrm{Cu}$ levels increase with age and reach adult levels by 6 months of age. In the current study, serum $\mathrm{Cu}$ levels in infants in the 2nd month were lower than those at 6 and 12 months. Serum $\mathrm{Cu}$ levels of infants in the total group varied between 8.60 and $26.70 \mu \mathrm{mol} / \mathrm{g}$ throughout the study period. In our study, changes in serum $\mathrm{Cu}$ level in infants were similar to those previously reported [5, 14, 55]. Infants' serum $\mathrm{Cu}$ levels at 12 months were higher; whereas maternal serum $\mathrm{Cu}$ levels were lower those at 2 and 6 months. There were positive correlations between maternal serum and hair $\mathrm{Cu}$ levels at all time periods (Table 6). These correlations showed that factors that affect the maternal $\mathrm{Cu}$ status after delivery did not change during the first year. All $\mathrm{Cu}$ analyses were performed using an atomic absorption spectrophotometer. We believe that there was minimum measurement error in our study.

The mean daily $\mathrm{Cu}$ intake of all infants at 12 months of age was $0.79 \pm 0.32 \mathrm{mg}$ in our study. The mean daily $\mathrm{Cu}$ intake among all mothers at all time periods was $1.38 \pm 0.62 \mathrm{mg}$. These values are close to the recommended intake for infants and mothers. The estimated safe and adequate daily $\mathrm{Cu}$ dietary intake recommended by the Food and Nutrition Board for adults is 1.50$3.00 \mathrm{mg} /$ day [56]. The average $\mathrm{Cu}$ intake of children is 0.80-1.90 mg/day [11]. Children (0-0.50 years) often have a low intake of $\mathrm{Cu}(0.08-0.16 \mathrm{mg} /$ day $)$ because of low $\mathrm{Cu}$ levels in breast milk [11]. Despite the declining $\mathrm{Cu}$ levels in breast milk during lactation, serum $\mathrm{Cu}$ levels in infants are increased, which suggests that the $\mathrm{Cu}$ requirements of infants are met. $\mathrm{Cu}$ in breast milk appears to be well absorbed and copper levels in breast milk are independent of maternal status [11, 55-57]. Salmenperaet al. [55] showed that serum $\mathrm{Cu}$ levels were not correlated with daily $\mathrm{Cu}$ intake in infants and in mothers. In our study, there were no relationships between daily intake of $\mathrm{Cu}$ and serum and hair $\mathrm{Cu}$ levels in infants and mothers. These findings suggest that $\mathrm{Cu}$ status is affected by multiple factors other than dietary intake.

The serum $\mathrm{Cu}$ level is a good indicator of $\mathrm{Cu}$ deficiency. However, neither serum $\mathrm{Zn}$ nor $\mathrm{Cu}$ reflects marginal status [26]. Therefore, hair $\mathrm{Cu}$ levels have been used as an indicator of copper status, particularly in infants $[53,58]$. There were negative correlations between 
Table 6 Significant correlations among trace elements in hair and serum

\begin{tabular}{|c|c|c|c|c|c|c|c|c|c|c|c|}
\hline Variants & $\begin{array}{l}\text { M serum Zn } \\
\text { (month 2) }\end{array}$ & $\begin{array}{l}\text { M hair Zn } \\
\text { (month 6) }\end{array}$ & $\begin{array}{l}\text { M serum Cu } \\
\text { (month 2) }\end{array}$ & $\begin{array}{l}\text { M serum Cu } \\
\text { (month 6) }\end{array}$ & $\begin{array}{l}\text { M serum Cu } \\
\text { (month 12) }\end{array}$ & $\begin{array}{l}M \text { hair } \mathrm{Cu} \\
\text { (month 2) }\end{array}$ & $\begin{array}{l}\mathrm{M} \text { hair } \mathrm{Cu} \\
\text { (month 6) }\end{array}$ & $\begin{array}{l}\text { M hair Cu } \\
\text { (month 12) }\end{array}$ & $\begin{array}{l}\text { I serum Fe } \\
\text { (month 6) }\end{array}$ & $\begin{array}{l}\text { I serum Fe } \\
\text { (month 12) }\end{array}$ & $\begin{array}{l}\text { I hair Zn } \\
\text { (month 12) }\end{array}$ \\
\hline \multirow{2}{*}{$\begin{array}{l}\mathrm{M} \text { hair } \mathrm{Zn} \text { at } \\
2 \text { months }\end{array}$} & ${ }^{*}-0.48$ & ${ }^{*} 0.55$ & & & & ${ }^{*}-0.36$ & & & & & \\
\hline & ${ }^{* *} 0.01$ & ${ }^{* *} 0.001$ & & & & ${ }^{* *} 0.05$ & & & & & \\
\hline \multirow{2}{*}{$\begin{array}{l}M \text { hair } Z n \text { at } \\
6 \text { months }\end{array}$} & & & & & & & ${ }^{*}-0.42$ & & & & \\
\hline & & & & & & & ${ }^{* *} 0.01$ & & & & \\
\hline \multirow{2}{*}{$\begin{array}{l}\text { M serum Fe at } \\
2 \text { months }\end{array}$} & & & $*-0,40$ & & & & & & & & \\
\hline & & & ${ }^{* *} 0.05$ & & & & & & & & \\
\hline \multirow{2}{*}{$\begin{array}{l}\text { M serum Fe at } \\
6 \text { months }\end{array}$} & & & & & & & & & ${ }^{*} 0.38$ & & \\
\hline & & & & & & & & & ${ }^{* *} 0.03$ & & \\
\hline \multirow{2}{*}{$\begin{array}{l}\text { M serum Fe at } \\
12 \text { months }\end{array}$} & & & & & & & & & & ${ }^{*} 0.44$ & \\
\hline & & & & & & & & & & ${ }^{* *} 0.04$ & \\
\hline \multirow{2}{*}{$\begin{array}{l}\text { M serum Cu at } \\
2 \text { months }\end{array}$} & & & & ${ }^{*} 0.62$ & ${ }^{*} 0.41$ & & & & & & \\
\hline & & & & ${ }^{* *} 0.001$ & ${ }^{* *} 0.01$ & & & & & & \\
\hline \multirow{2}{*}{$\begin{array}{l}\text { M serum Cu at } \\
6 \text { months }\end{array}$} & & & & & ${ }^{*} 0.49$ & & & & & & \\
\hline & & & & & ${ }^{* *} 0.01$ & & & & & & \\
\hline \multirow{2}{*}{$\begin{array}{l}\mathrm{M} \text { hair } \mathrm{Cu} \text { at } \\
2 \text { months }\end{array}$} & & & & & & & ${ }^{*} 0.78$ & ${ }^{*} 0.47$ & & & \\
\hline & & & & & & & ${ }^{* *} 0.01$ & ${ }^{* *} 0.00$ & & & \\
\hline \multirow{2}{*}{$\begin{array}{l}M \text { hair } \mathrm{Cu} \text { at } \\
6 \text { months }\end{array}$} & & & & & & & & ${ }^{*} 0.41$ & & & \\
\hline & & & & & & & & ${ }^{* *} 0.01$ & & & \\
\hline \multirow{2}{*}{$\begin{array}{l}\text { I serum Zn at } \\
6 \text { months }\end{array}$} & & & & & & & & & ${ }^{*}-0.42$ & & \\
\hline & & & & & & & & & ${ }^{* *} 0.01$ & & \\
\hline \multirow{2}{*}{$\begin{array}{l}\text { I hair Zn at } \\
6 \text { months }\end{array}$} & & & & & & & & & & & ${ }^{*} 0.51$ \\
\hline & & & & & & & & & & & ${ }^{* *} 0.00$ \\
\hline
\end{tabular}

Pearson's correlation analysis was used for serum

Spearman's correlation analysis was used for hair

$M$ mothers, I infants; ${ }^{*}$ r value; ${ }^{* *} p<$ value 
maternal hair $\mathrm{Cu}$ and $\mathrm{Zn}$ levels at 2 and 6 months after delivery in our study (Table 6).

\section{Iron}

Infants, children, and women during fertile years are particularly prone to Fe deficiency. In children, the highest prevalence of $\mathrm{Fe}$ deficiency is found between 4 months and 3 years of age because of rapid growth and inadequate dietary intake of Fe [9]. In our study, serum Fe levels decreased with age in mothers and infants. Infection was excluded in the subjects by their history, a physical examination, and complete blood count, which were performed at each clinic visit. We did not measure C-reactive protein levels, which may be a limitation of our study. Infants' and mothers' daily Fe intakes were less than the recommended intake [48]. There were positive correlations between infants' and mothers' serum Fe levels at 6 and 12 months (Table 6). This finding suggests that dietary Fe intake should be supplemented for mothers and infants. We did not evaluate Fe deficiency anemia and Fe deficiency. We only evaluated elemental Fe status and intake in mothers and infants after delivery for up to 1 year. Although ferritin and transferrin receptor need to be determined for Fe status, we only evaluated trace element levels in the study participants.

There is antagonism among $\mathrm{Zn}, \mathrm{Cu}$, and $\mathrm{Fe}$ absorption from the gastrointestinal tract. Increased Fe concentrations in the intestinal lumen may block the uptake of $\mathrm{Zn}$ $[14,15]$. Copper plays a role in Fe metabolism through ceruloplasmin [4]. Dietary Zn absorption is inhibited by Fe [15]. Infants' hair Zn levels and maternal and infants' hair $\mathrm{Cu}$ and serum Fe levels declined towards the end of the first year. Our study consisted of healthy children. We found a significant negative correlation between the infants' serum $\mathrm{Fe}$ and $\mathrm{Zn}$ levels at 6 months (Table 6). Voskaki et al. [3] reported significant correlations between serum $\mathrm{Zn}$ and $\mathrm{Cu}$ levels in children aged 13-14 years and their mothers. We did not find such a correlation in our study group. The reason for this discrepancy between studies may be due to our small sample size and different age.

Our study is one of the few studies on trace element levels of healthy breastfed infants and their mothers. Nevertheless, our study has some limitations. The families were generally from the middle socio-economic class and were not representative for all of the country. Evaluation of 3-day diets was based on the mothers' reports and our sample size was small. Therefore, further research is required on a larger scale with participation of families from all socio-economic classes. Additionally, dietary components, such as phytate, which affect $\mathrm{Zn}$, $\mathrm{Cu}$, and Fe metabolism, were not assessed. This is a confounder and could affect absorption of trace elements. We only evaluated elemental Fe status and Fe intake in mothers and infants after delivery for 1 year. Our study aim was not to investigate the mechanism of possible $\mathrm{Fe}$ deficiency anemia, but rather to investigate the natural course of $\mathrm{Fe}$ levels of breastfed infants and their mothers. However, in further studies, ferritin and transferrin receptor levels should be analyzed to understand the possible mechanisms of Fe deficiency anemia. Although levels of inflammation can affect serum $\mathrm{Cu}, \mathrm{Fe}$, and $\mathrm{Zn}$ concentration, even if subclinical [59], hair trace element levels are not affected by acute infection [27, 58]. We did not measure C-reactive protein levels, which may have also been a limitation of our study. However, infection was excluded in all subjects by recording the subjects' history, performing a physical examination, and measuring the complete blood count, at each clinic visit.

\section{Conclusions}

Infants' hair Zn levels, maternal and infants' hair $\mathrm{Cu}$ levels, and infants' and maternal serum Fe levels declined towards the end of first year. We observed a significant decline in hair $\mathrm{Zn}$ levels of infants at 6 and 12 months than those at 2 months. Children lose endogenous zinc from non-intestinal sites (i.e., urine and body surface) after 6 months of age. Therefore, they need more zinc from that age. Infants' and mothers' daily Fe intake was less than the recommended intake. There were positive correlations between infants' and mothers' serum Fe levels at 6 and 12 months. This finding suggested that dietary Fe intake should be supplemented for mothers and infants.

\section{Abbreviations}

Zn: Zinc; Cu: Copper; Fe: Iron.

\section{Competing interests}

The authors declare that they have no competing interests.

\section{Authors' contributions}

GG conceived the study, participated in its design and coordination, and drafted the manuscript. TAÖ conceived the study, participated in its design and coordination, drafted the manuscript, helped with the collection and acquisition of data, and performed trace element analysis. MSC and ÖD participated in the design of the study and drafted the manuscript. $\mathrm{HI}$ performed the statistical analyses. BO performed serum iron analysis. GS helped to coordinate and draft the manuscript. All of the authors read and approved the final version of the manuscript.

\section{Acknowledgments}

The project was supported by Istanbul University Research Fund (Project Nos: 498 and 518). The authors thank Nurşen and Doğan Toruş for their work of data entry, and the families of the children who helped to realize this study.

\section{Author details}

'Department of Pediatrics, Istanbul Faculty of Medicine, Istanbul University, Trace Element Unit, 34093 Istanbul, Turkey. ${ }^{2}$ Institute of Child Health and Istanbul School of Medicine Department of Pediatrics, Istanbul University, 34093 Istanbul, Turkey. ${ }^{3}$ Department of Pediatric Gastroenterology, Istanbul School of Medicine, Istanbul University, 34093 Istanbul, Turkey. ${ }^{4}$ Department of Public Health, Istanbul School of Medicine, Istanbul University, 34093 Istanbul, Turkey. ${ }^{5}$ Department of Biochemistry, Istanbul School of Medicine, Istanbul University, 34093 Istanbul, Turkey. 
Received: 23 February 2015 Accepted: 5 October 2015

\section{Published online: 14 October 2015}

\section{References}

1. Hegazy AA, Zaher MM, Abd El-Hafez MA, Morsy AA, Saleh RA. Relation between anemia and blood levels of lead, copper, zinc and iron among children. BMC Res Notes. 2010;3:1-9.

2. ESPGHAN. Iron, minerals and trace elements. J Pediatr Gastroenterol Nutr. 2005:41:S39-46.

3. Voskaki I, Arvanitidou V, Athanasopoulou H, Tzagkaraki A, Tripsianis G, Giannoulia-Karantana A. Serum copper and zinc levels in healthy Greek children and their parents. Biol Trace Elem Res. 2010;134:136-45.

4. Schneider JM, Fujii ML, Lamp CL, Lönnerdal B, Zidenberg-Cherr S. The prevalence of low serum zinc and copper levels and dietary habits associated with serum zinc and copper in 12-to 36-month-old children from low-income families at risk for iron deficiency. J Am Diet Assoc. 2007:107:1924-9.

5. Burjonrappa SC, Miller M. Role of trace elements in parenteral nutrition support of the surgical neonate. J Pediatr Surg. 2012;47:760-71.

6. Kleinman RE. Trace elements in pediatric nutrition handbook. 5th ed. Elk Grove: American Academy of Pediatrics; 2004. p. 313-21.

7. Kodama H. Trace element deficiency in infants and children. JMAJ. 2004:47:376-81.

8. Hambidge KM, Facog WD. Changes in plasma and hair concentrations of zinc, copper, chromium and manganese during pregnancy. Obstet Gynecol. 1974;44:666-72.

9. Lind T. Iron and zinc in infancy: Results from experimental trials in Sweden and Indonesia. Umeå University Medical Dissertations. 2004;87:1-108.

10. Abrams SA. New approaches to iron fortification: Role of bioavailability studies. Am J Clin Nutr. 2004;80:1104-5.

11. Lönnerdal B. Bioavailability of copper. Am J Clin Nutr. 1996;63:821S-9.

12. Wu X, Liu Z, Guo J, Wan C, Zhang T, Cui H, et al. Influence of dietary zinc and copper on apparent mineral retention and serum biochemical indicators in young male mink (Mustela vison). Biol Trace Elem Res. 2015;165:56-66.

13. Jacks B, Sall M, Jacks G. A first assessment of zinc intake in Niger Inland Delta, Mali. Sight and Life. 2008;2:27-32.

14. Ece A, Uyanik BS, Iscan A, Ertan P, Yigitoglu MR. Increased serum copper and decreased serum zinc levels in children with iron deficiency anemia. Biol Trace Elem Res. 1997;59:31-9.

15. Lönnerdal B. Dietary factors influencing zinc absorption. J Nutr. 2000:130:1378-83

16. Gibson RS. Trace element deficiencies in humans. Can Med Assoc J. 1991:145:231.

17. Jones AA, Di Silvestro RA, Coleman M, Wagner TL. Copper supplementation of adult men: effect on blood copper enzyme activities and indicators of cardiovascular disease risk. Metabolism. 1997:46:1380-3.

18. Zlotkin SH, Schauer C, Agyei SO, Wolfson J, Tondeur MC, Asante KP, et al. Demonstrating zinc and iron bioavailability from intrinsically labeled microencapsulated ferrous fumarate and zinc gluconate sprinkles in young children. J Nutr. 2006;136:920-5.

19. L'Abbe MR, Friel JK. Copper status of very-low-birth-weight infants during the first 12 months of infancy. Pediatr Res. 1992;32:183-8.

20. Cordano A, Baertl JM, Graham GG. Copper deficiency in infancy. Pediatrics. 1964:34:324-36

21. Levy Y, Zeharia A, Grunebaum M, Nitzan M, Steinherz R. Copper deficiency in infants fed cow milk. J Pediatr. 1985;106:786-8.

22. Shazia Q, Mohammad ZH, Rahman T, Shekhar HU. Correlation of oxidative stress with serum trace element levels and antioxidant enzyme status in beta thalassemia major patients: A review of the literature. Anemia. 2012;2012:270923.

23. Worwood M. Iron and other trace metals. In: Jacobs A, Worwood M, editors. Iron and biochemistry and medicine. London and New York: Academic; 1974. p. 335-62

24. Monajemzadeh SH, Zarkesh MR. Iron deficiency anemia in infants aged 12-15 months in Ahwaz, Iran. Indian J Path Microbiol. 2009:52:182-4.

25. Brown $\mathrm{KH}$. Effect of infections on plasma zinc concentration and implications for zinc status assessment in low-income countries. Am J Clin Nutr. 1998;68:425S-9.
26. Hinks LJ, Clayton BE, Lloyd RS. Zinc and copper concentrations in leucocytes and erythrocytes in healthy adults and the effect of oral contraceptives. J Clin Pathol. 1983;36:1016-21.

27. Hotz C, Brown $\mathrm{KH}$. Overview of zinc nutrition in assessment of the risk of zinc deficiency in populations and options for its control. Food Nutr Bull. 2004:25(1 Suppl 2):96-203.

28. McMaster D, Lappin TR, Halliday HL, Patterson CC. Serum copper and zinc levels in the preterm infant. A longitudinal study of the first year of life. Biol Neonate. 1983;44:108-13.

29. Bundak R, Furman A, Günöz H, Darendeliler F, Baş F, Neyzi O. Body mass index references for Turkish Children. Acta Pediatric. 2006;95:194-8.

30. Büyüyorum. http://www.itf.istanbul.edu.tr/cocukhast/buyuyorumweb/ Index.htm. Accessed 15 Jun 2015

31. Emmett PM, North K, Noble S. Types of drinks consumed by infants at 4 and 8 months of age: a descriptive study. Public Health Nutr. 2000;3:211-7.

32. Chou PP. Zinc. In: Pesce AJ, Kaplan LA, editors. Methods in clinical chemistry. St. Louis, Missouri: The C.V. Mosby Company; 1987. p. 596-602.

33. Taylor A, Bryant TN. Comparison of procedures for determination of copper and zinc serum by atomic absorption spectroscopy. Clin Chim Acta. 1981;110:83-90.

34. Alcock NW. Copper. In: Pesce AJ, Kaplan LA, editors. Methods in clinical chemistry. St. Louis, Missouri: The C. V. Mosby Company; 1987. p. 527-38.

35. Chen XC, Yin TA, He JS, Ma QY, Han ZM, Li LX. Low levels of zinc in hair and blood, pica, anorexia and poor growth in Chinese preschool children. Am J Clin Nutr. 1985:42:694-700.

36. Wu AHB. General clinical tests. In: Wu AHB, editor. Tietz clinical guide to laboratory tests. 4th ed. St. Louis,Missouri: WB Saunders Company; 2006. p. 32-1202.

37. Lehmann HP, Henry JB. SI units. In: Henry JH, editor. Clinical diagnosis and management by laboratory methods. 20th ed. Philadelphia: WB Saunders Company; 2001. p. 1426-41.

38. Lin CN, Wilson A, Church BB, Ehman S, Roberts WL, McMillin GA. Pediatric reference intervals for serum copper and zinc. Clin Chim Acta. 2012:413:612-5.

39. Tietz NW. Tables of normal values in fundamentals of clinical chemistry. Philadelphia: WB Saunders Company; 1976. p. 1207-27.

40. Moser PB, Reynolds RD, Acharya S, Howard MP, Andon MB, Lewis SA. Copper, iron, zinc and selenium dietary intake and status of lactating women and their breast-fed infants. Am J Clin Nutr. 1988;47:729-34.

41. Dijkhuizen MA, Wieringa FT, West CE. Concurrent micronutrient deficiencies in lactating mothers and their infants in Indonesia. Am J Clin Nutr. 2001:73:786-91.

42. Fung EB, Ritchie LD, Woodhouse LR, Roehl R, King JC. Zinc absorption in women during pregnancy and lactation: A longitudinal study. Am J Clin Nutr. 1997;66:80-8.

43. Krebs NF, Westcott J. Zinc and breastfed infants: If and when is there a risk of deficiency. Adv Exp Med Biol. 2002;503:69-75.

44. Krebs NF, Reidinger CJ, Hartley S, Robertson AD, Hambidge KM. Zinc supplementation during lactation: effects on maternal status and milk zinc concentrations. Am J Clin Nutr. 1995;61:1030-6.

45. Nakamori M, Ninh NX, Isomura H, Yoshiike $N$, Hien VTT, Nhug BT, et al. Nutritional status of lactating mothers and their breast milk concentration of iron, zinc and copper in rural Vietnam. J Nutr Sci Vitaminol. 2009;55:338-45.

46. Macdonald LD, Gibson RS, Miles JE. Changes in hair zinc and copper concentrations of breast fed and bottle fed infants during the first six months. Acta Pediatr Scand. 1982;71:785-9.

47. Taneli B. Zinc in Anatolian population. Ege J Med. 2005;44:1-10.

48. Dolphin AE, Goodman AH. Maternal diets, nutritional status and zinc contemporary Mexican infants' teeth: Implications or reconstructing paleo diets. Am J Physic Anthrop. 2009;140:390-409.

49. Dietary reference intakes: Dietary reference intakes for vitamin $A$, vitamin $K$ arsenic, boron, chromium, copper, iodine, iron, manganese, molybdenum, nickel, silicon, vanadium and zinc. 2001. http://www.iom.nationalacademies. org/Reports/2001/Dietary-Reference-Intakes-for-Vitamin-A-Vitamin-K-ArsenicBoron-Chromium-Copper-iodine, iron, manganese, molybdenum, nickel, silicon, vanadium and zinc. Accessed 15 Feb 2015

50. Sian L, Krebs NF, Westcott JE, Fengliang L, Tong L, Miller LV, et al. Zinc homeostasis during lactation in a population with a low zinc intake. Am J Clin Nutr. 2002;75:99-103.

51. Gibson RS. Content and bioavailability of trace elements in vegetarian diets. Am J Clin Nutr. 1994;59:1223S-32 
52. Park HS, Shin KO, Kim JS. Assessment of reference values for hair minerals of Korean preschool children. Biol Trace Elem Res. 2007;116:119-30.

53. Dongarra G, Lombardo M, Tamburo E, Varrica D, Cibella F, Cuttitta G. Concentration and reference interval of trace elements in human hair from students living in Palermo, Sicily (Italy). Environ Toxicol Pharmacol. 2011;32:27-34

54. Eatough DJ, Christensen JJ, Izatt RM, Hartley C. Level of selected elements in human hair. In: Brown AC, editor. The first human hair symposium. New York: Medcom Press; 1974.

55. Salmenpera L, Perheentupa J, Pakarinen P, Siimes MA. Cu nutrition in infants during prolonged exclusive breast-feeding: low intake but rising serum concentrations of Cu and ceruloplasmin. Am J Clin Nutr. 1986;43:251-7.

56. Committee on Dietary Allowances. Food and Nutrition Board. National Research Council. Recommended dietary allowances. 10th ed. Washington, DC: National Academy Press; 1989.

57. Feely RM, Eitenmiller RR, Jones JB, Barnhart H. Copper, iron and zinc contents of human milk at early stages of lactation. Am J Clin Nutr. 1983;37:443-8

58. Valkovic V. The role of trace elements. In: Valkovic V, editor. Trace elements in human hair. New York and London: Garland STPM Press; 1977. p. 89-141.

59. Raiten DJ, Ashour FAS, Ross AC, Meydani SN, Dawson HD, Stephensen CB,

et al. Inflammation and Nutritional Science for Programs/Policies and Interpretation of Research Evidence (INSPIRE). J Nutr. 2015;145:1039S-108.

\section{Submit your next manuscript to BioMed Central and take full advantage of:}

- Convenient online submission

- Thorough peer review

- No space constraints or color figure charges

- Immediate publication on acceptance

- Inclusion in PubMed, CAS, Scopus and Google Scholar

- Research which is freely available for redistribution 